Research Article

\title{
Husband's Support is a Main Factor Associated with Contraceptive Practices
}

\author{
Dukungan Suami adalab Faktor Utama yang Berbubungan \\ dengan Perilaku Penggunaan Kontrasepsi
}

\author{
Darrell Fernando, Rachmat Dediat
}

Department of Obstetrics and Gynecology

Faculty of Medicine University of Indonesial

Dr. Cipto Mangunkusumo Hospital

Jakarta

\begin{abstract}
Objective: To determine factors associated with contraceptive practices in Palabuhanratu, West Java.

Method: We conducted a cross-sectional study at the Obstetrics and Gynecologic ward of Local General Hospital of Palabuhanratu District, between March and June 2012. Data was collected using directed interview method by investigators and midwives, using non-validated questionnaires. Statistical analysis was performed using SPSS 20.0, utilizing Chi-Square test for nominal data and Kruskal-Wallis test for numerical data.

Result: We obtained 71 samples. The only factors which are significant were age group of $20-35$ years old $(\mathrm{OR}=3.5,95 \% \mathrm{CI}=1.1-11.1$, $\mathrm{p}=0.025)$ and husband's support $(\mathrm{OR}=14.67,95 \% \mathrm{CI}=1.52-141.18$, $\mathrm{p}=0.012$ ). The most recognized contraceptive methods familiar to our respondents were injection $(94.4 \%)$ and pills $(93.0 \%)$, and the most useful source of information on contraception was medical personnel $(73.2 \%)$.

Conclusion: Husband's support is a main factor associated with contraceptive practice. The choice of contraceptive method should be adjusted according to the ability and desire of patients to prevent failures in family planning.

[Indones J Obstet Gynecol 2015; 3: 123-126]

Keywords: associated factors, contraception, husband's support
\end{abstract}

\begin{abstract}
Abstrak
Tujuan: Menentukan faktor yang berbubungan dengan penggunaan kontrasepsi di Palabuhanratu, Jawa Barat.

Metode: Studi ini menggunakan rancangan potong lintang, dan dilakukan di Ruang Perawatan Obstetri dan Ginekologi, RSUD Palabuhanratu, Jawa Barat, mulai Maret 2012 bingga Juni 2012. Data diperoleh melalui wawancara terpimpin oleb peneliti dan bidan menggunakan kuesioner yang tidak tervalidasi. Analisis statistik dilakukan dengan program SPSS 20.0, menggunakan uji Chi-square untuk data nominal dan uji Kruskal-Wallis untuk data numerik.

Hasil: Diperoleh 71 sampel. Faktor yang secara signifikan berbubungan dengan penggunaan kontrasepsi adalab kelompok umur 20-35 tabun $(\mathrm{OR}=3,5, \mathrm{IK} 95 \%=1,1-11,1, p=0,025)$ dan dukungan suami $(\mathrm{OR}=14,67$, $I K 95 \%=1,52-141,18, p=0,012)$. Metode kontrasepsi yang paling banyak diketabui responden adalab suntik (94,4\%) dan pil (93,0\%). Sumber informasi mengenai kontrasepsi yang dirasakan paling bermanfaat adalah tenaga medis $(73,2 \%)$.
\end{abstract}

Kesimpulan: Dukungan suami adalab faktor utama yang berbubungan dengan penggunaan kontrasepsi. Piliban metode kontrasepsi harus disesuaikan dengan kemampuan dan keinginan pasien.

[Maj Obstet Ginekol Indones 2015; 3: 123-126]

Kata kunci: dukungan suami, faktor yang berhubungan, kontrasepsi

Correspondence: Darrell Fernando. Department of Obstetrics and Gynecology, Faculty of Medicine, University of Indonesia - Dr. Cipto Mangunkusumo National Hospital. Jln. Salemba Raya No 4, Jakarta 10430, Mobile: 813899 00846, Email: dr.darrellfernando@gmail.com

\section{INTRODUCTION}

Indonesia is the fourth most populated country in the world. In 2011, Indonesia has a population amounting to around 240 million individuals with a population growth of $1.49 \%$ per year. ${ }^{1}$ The relatively high population growth may impede target achievement of the Millennium Development Goals (MDG) 2015 in Indonesia.

Contraception has been considered as the main key to accomplish MDGs targets. ${ }^{2}$ The Indonesian MDG progress report has generally suggested that there is increasing use of modern contraceptive methods. However, there are some areas regarded as the untouchables, which have no access to Family Planning and in those areas, the use of modern contraceptive remains low. This issue is consistent with the number of reproductive age couples who want to pace or limit pregnancies but do not use any contraceptive methods (unmet needs). The National MDG report in 2011 indicated that there was $9.7 \%$ of unmet needs and the rate has remained the same since $1997 .^{3}$

Some efforts should be taken to reduce the unmet needs by identifying difficulties in providing contraceptive service, which indeed are different for 
each region or population. In this study, factors correlated with positive attitude toward the use of contraceptive methods were investigated in Palabuhanratu district in West Java.

\section{METHODS}

This study used a cross-sectional design and was conducted at the Obstetrics and Gynecology ward of Local General Hospital of Palabuhanratu District, West Java, between March-April and June 2012. The inclusion criteria were married reproductive age women, who were willing to be the respondents, while the exclusion criteria were women with infertility, parity $\leq 1$, or marital status of widow/divorced. The obtained sample size was 71 subjects. Data was collected by directed interview method by investigators and midwives, using non-validated questionnaires. Data was processed using SPSS version 20.0. Data analysis was performed using Chi-Square test for nominal data and Kruskal-Wallis test for numeric data.

Our definition for positive attitude toward contraceptive method was a woman who ceased to use contraceptive method because she was planning for pregnancy with birth spacing between her current and previous pregnancy of at least 2 years, or a woman who was pregnant due to failure of contraceptive method, or a woman who was using contraception. Meanwhile, the negative attitude included women who did not use contraception or refused to use contraception.

\section{RESULTS}

Out of 71 samples, we found 54 samples $(76.1 \%)$ with positive attitude and 17 samples $(23.9 \%)$ with negative attitude. Baseline data of all respondents is presented in Table 1.

Table 1. Baseline Data of All Respondents

\begin{tabular}{cc}
\hline \multicolumn{1}{c}{ Parameter } & Frequency $(\%)$ \\
\hline Age (years) & $0(0)$ \\
$<20$ & $2(2.8)$ \\
$20-25$ & $26(36.6)$ \\
$26-30$ & $21(29.6)$ \\
$31-35$ & $22(31.0)$ \\
$>35$ & \\
Educational status & $56(78.9)$ \\
$\leq 9$ years & $15(21.1)$ \\
$>9$ years & \\
Income & $55(77.5)$ \\
IDR $<1$ million & $16(22.5)$ \\
IDR $\geq 1$ million & \\
Number of marriage & $58(81.7)$ \\
1 & $13(18.3)$ \\
$>1$ & \\
Parity & $33(46.5)$ \\
2 & $33(46.5)$ \\
$3-5$ & $5(7.0)$ \\
$>5$ &
\end{tabular}

*IDR = Indonesian Rupiah

Table 2. Results of Comparative Analysis Between Investigated Factors and Attitude Towards Contraception

\begin{tabular}{lcc}
\hline \hline \multicolumn{1}{c}{ Factors } & Odds ratio (95\%CI) & p-value \\
\hline Age 20-35 years & $3.5(1.1-11.1)$ & 0.025 \\
Mother's education $>9 \mathrm{yr}$ & $0.55(0.16-1.90)$ & 0.331 \\
Husband's education $>9 \mathrm{yr}$ & $0.58(0.18-1.88)$ & 0.365 \\
Income $\geq 1$ million/month & $1.48(0.37-5.97)$ & 0.745 \\
Number of marriage & - & 0.416 \\
Parity & - & 0.798 \\
Desire of having $\leq 2$ children & $0.35(0.11-1.08)$ & 0.062 \\
Perception on obligatory family planning & $5.57(0.85-36.66)$ & 0.085 \\
Working mother & $0.94(0.17-5.14)$ & 1.000 \\
Husband's support & $14.67(1.52-141.18)$ & 0.012 \\
Family's support & $6.47(0.55-75.84)$ & 0.239 \\
Support from traditioinal and local environment & $3.47(0.45-26.73)$ & 0.241 \\
Support from health care personnel & $5.23(1.039-26.33)$ & 0.052 \\
\hline \hline
\end{tabular}


A comparative analysis was performed comparing the investigated factors and respondents' attitude towards contraception. Analysis results and the significance are shown in Table 2.

The results indicate that factors which had significant correlation with the use of contraception were age of 20-35 years old $(\mathrm{OR}=3.5,95 \% \mathrm{CI}=1.1$ $11.1)$ and husband's support $(\mathrm{OR}=14.67,95 \% \mathrm{CI}=$ 1.52-141.18). Other factors which also showed significant trend were support from health care personnel $(p=0.052)$ and desire of having $\leq 2$ children $(\mathrm{p}=0.062)$.

The most recognized contraceptive methods by our respondents were injection $(94.4 \%)$ and pill $(93.0 \%)$, and the most useful source of information on contraception was medical personnel $(73.2 \%)$. The detailed recognized contraceptive methods and the most useful source of information are shown in Table 3 and 4.

Table 3. Contraceptive Method Known by Respondents

\begin{tabular}{lc}
\hline \hline \multicolumn{1}{c}{ Contraceptive Methods } & Percentage (\%) \\
\hline Injectables & $94.4 \%$ \\
Pill & $93 \%$ \\
Intrauterine device & $54.9 \%$ \\
Implants & $52.1 \%$ \\
Sterilization & $39.4 \%$ \\
Condom & $29.6 \%$ \\
Lactational amenorrhea & $2.8 \%$ \\
Calendar system & $1.4 \%$ \\
Emergency contraception & $1.4 \%$ \\
\hline \hline
\end{tabular}

Table 4. The Most Useful Source of Information on Contraception

\begin{tabular}{lc}
\hline \multicolumn{1}{c}{ Source of information } & Percentage (\%) \\
\hline Medical personnel & $73.2 \%$ \\
Friend / neighbour & $46.5 \%$ \\
Family & $45.1 \%$ \\
Electronic media & $28.2 \%$ \\
Printed media & $9.9 \%$ \\
School & $2.8 \%$ \\
\hline \hline
\end{tabular}

In the group of positive attitude toward contraception, we found that $37 \%$ respondents experienced failure of family planning. The most common contraceptive method in the group with failed family planning was pills $(60 \%)$, followed by injection $(30 \%)$.

\section{DISCUSSION}

Among the analyzed factors on their correlation with positive attitude toward applied contraception, age group of 20-35 years and husband's support were the only factors found to be significant. First, it should be noted that our study was a cross-sectional study; therefore, the calculation of odds ratio could only provide the correlation of association, instead of causality.

The age group in our study was categorized into the group of women delaying pregnancy $(<20$ years), the group of women spacing pregnancy $(20$ 35 years), and the group of women who does not desire any pregnancy in the future ( $>35$ years). In statistical analysis, the first and the third group were combined as a variable. A significant value found in the age group of 20-35 years $(O R=3.5$, $95 \% \mathrm{CI}=1.1-11.1)$ showed that there was awareness in the group of spacing pregnancy. Moreover, subjects in the age group of $<20$ years were more likely to not use any contraceptive method due to their desires of having a first child. However, it should be noted that our study was conducted at the Obstetrics and Gynecology ward, which may cause selection bias since it did not include women who were using contraception and who were not pregnant.

Husband's support was the only modifiable factor found to be significant, in which it will increase the possibility of contraceptive method used by 14.67 folds $(95 \% \mathrm{CI}=1.52-141.18)$. Various studies have reported that husband's support was correlated to the use of contraception. ${ }^{4,5}$ It has been proven that if the husband has the final decision on contraception in a household, the couple tends not to use contraception. ${ }^{6}$ Therefore, communication between husband and wife is also an important factor in family planning. ${ }^{7}$ Unfortunately, approximately only $60.3 \%$ of husbands discuss about family planning with their wife. Furthermore, in $33.3 \%$ of cases, husbands are the sole and final decision makers. ${ }^{8}$ Information and counseling on contraception and family planning should be provided for the couple, husband and wife, and not only for single participants. ${ }^{9}$

Support from medical personnel, although was not significant in our study, is one of the important components increasing the coverage of contraception. ${ }^{5}$ It is confirmed by our findings that information about contraception had been perceived as the most valuable when it came from medical personnel. 
In our study, the education levels of husband and wife were not significantly correlated to positive attitude towards the use of contraception. It indicates that providing special information about contraception and family planning is more essential as the information is rarely discussed in formal educational activity.

Family support and the support from traditional and local environment had no significant contribution on positive attitude towards the use of contraception. It demonstrates that the support of both factors tend to have equal distribution in both behavioral groups. In other words, there were no family or local traditional habits that become obstacles against the use of contraception in Palabuhanratu district. This finding is different from results in a Cambodian study, which demonstrated that family prohibition would reduce the use of contraception by $50 \%{ }^{4}$

The most recognized contraceptive method by our respondents was injection (94.4\%), which was followed by pills (93\%), and IUD (54.9\%). We can conclude that the most favorable contraceptive method was hormonal contraception. Our interview results revealed that many respondents were afraid to use IUD due to various reasons, such as their fear of IUD insertion pain and their reluctance of having a foreign body inside their womb. Similar findings have been reported in India, where many women refused to use IUD and preferred to listen to inputs from their friends and family than the information from health care personnel. ${ }^{10}$ In women with high parity or age $>35$ years, specific education on long-term contraceptive methods should be provided. Considering that most respondents prefer hormonal contraceptive method, the intervention should be emphasized on implant as a contraceptive method.

In the group of subjects with positive family planning attitude, there was $37 \%$ of respondents who had experienced contraceptive failure. The most ineffective contraceptive method was pills $(60 \%)$, followed by injection $(30 \%)$. The high rate of contraceptive failure may be caused by bad choice when selecting contraceptive methods or errors when using the contraception. Therefore, counseling on the available contraceptive method is very important and it may help patients to select the best method for them according to their needs, know-ledge and ability. The choice of contraceptive me-thod should be adjusted to the ability and desire of patients to prevent failures in family planning.

\section{CONCLUSION}

Husband's support is a main factor associated with contraceptive practice. The choice of contraceptive method should be adjusted with the ability and desire of patients to prevent failures in family planning.

\section{ACKNOWLEDGEMENTS}

We would like to express our gratitude to dr. Achmad Junaedi, SpOG and dr. Edy D. Amansari, SpOG who approved this research, and to the midwives of RSUD Palabuhanratu for helping us collect the data from patients.

\section{REFERENCES}

1. National Statistical Bureau. Statistik Indonesia 2011. [Accessed on 20 August 2012]. Available from: URL: http://www.bps.go.id/flip/flip11/index3.php.

2. Population Action International. The Key to Achieving the Millennium Development Goals: Universal Access to Family Planning and Reproductive Health. [Accessed on 6 March 2013]. Available from: URL:http:// populationaction.org/wp-content/uploads/2012/01/PAI-MDG-br ief.pdf.

3. Indonesian National Development Planning Agency. Report on The Achievement of The Millenium Development Goals Indonesia 2010. Available from: URL:http: //www.undp.or.id/pubs/docs/MDG 2010 Report Final Full LR.pdf.

4. Samandari G Speizer IS, OConnell K. The role of social support and parity in contraceptive use in Cambodia. Int Perspect Sex Reprod Health 2010; 36(3): 122-31.

5. Samandari G OConnell KA. "If we can endure, we continue": understanding differences between users, discontinuers, and non-users of hormonal contraceptive methods in Pursat Province, Cambodia. Women Health 2011; 51(3): 256-78.

6. Gipson JD, Muntifering G, Chauwa FK, et al. Assessing the importance of gender roles in couples' home-based sexual health services in Malawi. Afr J Reprod Health 2010; 14(4): 61-71.

7. Ogunjuyigbe PQ Ojofeitimi EQ Liasu A. Spousal communication, changes in partner attitude, and contraceptive use among the Yorubas of southwest Nigeria. Indian J Community Med 2009; 34(2): 112-6.

8. Berhane A, Biadgilign S, Amberbir A, Morankar S, Deribe $\mathrm{K}$. Men's knowledge and spousal communication about modern family planning methods in Ethiopia. Afr J Reprod Health 2011; 15(4): 24-32.

9. Barden-OFallon JL, Speizer IS. Indonesian couples' pregnancy ambivalence and contraceptive use. Int Pers-pect Sex Reprod Health 2010; 36(1): 36-43.

10. Rustagi N Taneja D, Kaur R, et al. Factors affecting contraception among women in a minority community in Delhi: a qualitative study. HPPI 2010; 33 (1): 10-5. 